\title{
Dispersion in Analyst Forecasts and the Profitability of Earnings Momentum Strategies
}

\author{
Andreas Dische*
}

First Draft: May 2001

Comments welcome

* University of St. Gallen in Switzerland and Visiting Fellow at Harvard University. I thank I/B/E/S Inc. for providing the earnings expectation data as part of a broad academic program to encourage earnings expectations research and the Swiss National Science Foundation for financial support.

Correspondence to: Andreas Dische, 23 Pearson Rd., Somerville, MA 02144, USA; phone: +1-617-776-4336; email: andreas.dische@unisg.ch 


\title{
Dispersion in Analyst Forecasts and the Profitability of Earnings Momentum Strategies
}

\begin{abstract}
It is a well documented phenomenon that stock prices underreact to news about future earnings and drift in the direction suggested by revisions in analysts' earnings forecasts. This paper shows that the dispersion in analysts' consensus forecasts contains incremental information to predict future stock returns. Higher abnormal returns can be achieved by applying an earnings momentum strategy to stocks with a low dispersion. This finding supports one of the recent behavioral models in which investors focus too little on the weight of new evidence and conservatively update their beliefs in the right direction, but by too little in magnitude with respect to more objective information.
\end{abstract}

Keywords: analyst forecasts, dispersion, momentum, underreaction, investor behavior. JEL classification: G12, G14. 
The following study demonstrates how portfolio managers can profit from the earnings forecasts of financial analysts. Academic research has long been skeptical whether security analysts can forecasts stock returns and claims since Cowles' (1933) article that abnormal returns cannot be achieved on the basis of their publicly available information. On the other hand, brokerage houses devote extensive resources to predict firms' expected earnings as a basis for their stock recommendations. Today the reports of financial analysts are broadly available over electronic vendors and employed by most funds in their stock selection process. An empirical analysis of the value that is potentially created by their research reports is therefore of central importance to investment professionals and the understanding of financial markets.

The debate on the value of analyst research has been revived by Womack (1996), who examines buy and sell recommendations of major brokerage houses. He finds that stock prices are influenced by analysts' recommendations and interestingly not only at the immediate time of their announcements but also in subsequent months, showing an exploitable post-recommendation drift. Barber et. al. (2001) remain skeptical and point out that frequent portfolio rebalancing is required to capture the excess returns of such a trading strategy and that the entailing trading costs lead to net returns that are not reliably greater than zero. In a recent paper, Cooper, Day, and Lewis (2001) argue that forecasts revisions by analysts who lead the consensus are more informative than those by analysts who follow the herd.

This article builds on the idea that more valuable earnings forecasts can be identified and shows that they can actually be used to achieve a superior investment performance. The evidence on the price formation following revisions in earnings forecasts in this paper demonstrates that the information inherent in the dispersion of analyst forecasts provides incremental value to predict future stock returns. Portfolio managers can obtain the degree of dispersion from providers of analyst estimates such as IBES and thereby enhance the use of consensus forecasts in their stock selection process.

The results of this paper document that a strategy of buying stocks with strong upward revisions in analyst earnings forecasts and selling short stocks with strong downward revisions yields abnormal returns. More importantly, it is shown that such an approach can be further improved if it is implemented on a portfolio of firms with a low dispersion in consensus forecasts. Significantly higher abnormal returns are then found throughout the full sample period and in subperiods. 
The underreaction to earnings news and the ability to achieve superior returns by exploiting the following drift in stock prices present some of the most striking challenges to the concept of market efficiency. Since these facts cannot be explained by economically meaningful risk factors, traditional asset-pricing models fail to explain this phenomenon. Behavioral explanations, where investors suffer from systematic biases in their judgment, have recently been proposed to explain the predictability in cross-sectional stock returns. Fama (1998) attempts to uphold the case for efficient markets and argues that these theories rationalize already known empirical studies and that any new model should be judged on its ability to pass out-of-sample tests. The following analysis takes a step in this direction and concludes that the new empirical results favor one of the new theories of behavioral finance.

The paper proceeds as follows. The next section reviews related empirical studies and then discusses the new behavioral finance models. Section II motivates the following empirical analysis by looking at psychological evidence on how people form beliefs. Section III describes the available data and the characteristics of the chosen sample. Section IV analyses the market reaction to analysts' earnings revisions, and Section $\mathrm{V}$ examines the impact of dispersion in consensus forecasts on the profitability of momentum strategies. Section VI summarizes the findings.

\section{Related Literature}

Ball and Brown (1968) first observed the so-called post-earnings-announcement drift, where cumulative abnormal returns drift upwards for firms that produced positive earnings surprises and down for firms with disappointing news. The striking finding is that even though the price reaction on the announcement date is large, it appears to be incomplete and the subsequent drift indicates that initially the information does not fully flow into security prices and is thus exploitable by investors. Despite the thirty years which have passed since their widely recognized publication, the effect still remains intact and contradicts the semi-strong form of market efficiency, which rules out that superior performances can be achieved by trading on public information.

Bernard and Thomas (1989) demonstrate that the proposed trading strategy is not risky along any meaningful economic factors and show that implementation problems and transaction costs are negligible compared to the abnormal returns, even for individual investors. A related measure of earnings news that is closely followed by investors is the change in analysts' earnings forecasts, which are revised on a regular basis. Dische and Zimmermann (1999) examine consensus forecasts for the 
Swiss market and document that buying stocks with the most positive upward revision and selling stocks with strong downward revisions yields significant abnormal returns. These studies can be summarized as evidence for earnings momentum in stock returns. A related effect at medium term horizons is price momentum, where past winners continue to perform well and past losers continue to perform poorly. An impressive magnitude of one percent abnormal return per month is reported by Jegadeesh and Titman (1993) for a self-financing price momentum strategy. Subsequently Chan, Jegadeesh, and Lakonishok (1996) showed that the each of these variables - past returns, as well as unexpected earnings and revisions in analysts' forecasts - have marginal power to predict subsequent returns. It is increasingly clear that these results cannot be explained by a risk story and even Fama and French (1996) acknowledge that they are the main contradiction to their three-factor model.

The profitability of price momentum is confirmed by Rouwenhorst $(1998,1999)$ for stocks in several European and emerging stock markets, though Haugen and Baker (1996) find that momentum is weak in Japan. The relative performance of global equity markets is examined by Chan, Hameed, and Tong (2000), who show that momentum strategies can be implemented on international stock market indices. For the US market, Jegadeesh and Titman (2001) report that momentum profits have continued in the 1990s, suggesting that the original results were not due to data snooping bias. Looking at the entire post 1926 era, Grundy and Martin (2001) document that momentum profits are remarkably stable across subperiods and not explained by time-varying factor exposures, crosssectional differences in expected returns, or industry effects.

This body of evidence for the predictability in cross-sectional stock returns has inspired a new theory of behavioral finance where security prices are set by less than fully rational investors that are affected by human biases which have been documented in the psychology literature on how ordinary people actually behave. Three prominent models have been proposed that will be discussed next.

\section{A. Three New Theories of Behavioral Finance}

Hong and Stein (1999) model a market with two types of investors: newswatchers and momentum traders. Both groups are boundedly rational and are able to process only a subset of all available information. The first group trades only on private information about fundamentals and the second only on past price movements. The authors make a further key assumption: fundamental news diffuses slowly across the newswatcher population. As a result, the momentum traders can profit from trend- 
chasing in the short run. As more momentum traders benefit from this underreaction and come into the market, it turns into overreaction at longer horizons.

Daniel, Hirshleifer, and Subrahmanyam (1998) propose an alternative theory that is based on variations in the confidence of investors arising from biased self-attribution. Their model is motivated by experiments in cognitive psychology, which show that individuals often overestimate their own abilities. If an investor overestimates his ability to generate valuable trading information, he will be overconfident with regard to the information he has generated himself, but not about public signals received by all. Though investors underreact on average to public signals, they can stimulate additional overreaction to previous private signals in the short run. Eventually prices will decline as the cumulative public signal becomes more precise and investors put less weight on their private information. The authors argue that this feature can potentially explain positive short-lag autocorrelations (momentum), short-run earnings drifts as well as negative correlations between future returns and long-term stock market and accounting performance. They refer to psychological evidence from Einhorn (1980) who argues that individuals are overconfident in settings where feedback on information is slow or inconclusive. Consequently mispricing should be stronger in stocks which are harder to value. The model suggests that return predictability will be pronounced for firms with the greatest information asymmetries.

Barberis, Shleifer, and Vishny (1998) propose a third model that is based on investor sentiment, where people update their beliefs based on the strength and weight of new evidence. They refer to strength as the salience of information and weight to its statistical informativeness, such as sample size or credibility. Their model is motivated a psychological phenomenon called conservatism, which has been documented by the psychologists Griffin and Tversky (1992). They found out that people focus too much on the strength of information and too little on its statistical weight, relative to a rational Bayesian. Individuals update their posterior beliefs in the right direction, but by too little in magnitude. Barberis, Shleifer, and Vishny (1998) conclude that individuals might disregard the full information content of an earnings announcement, because they believe that the new number contains a large temporary component, and still adhere at least partially to their prior estimates. As a result, investors adjust their valuations only partially and prices will underreact to earnings news.

Each of the three models seems plausible. It is therefore the task of positive science to find empirical evidence which preferably favors one of the new theories. Momentum strategies have been 
refined in two recent studies which improve the profits from simple momentum strategies and that are relevant for the current discussion in behavioral finance.

\section{B. Recent Out-of-Sample Tests}

A first approach is made by Hong, Lim, and Stein (2000), who test the model of Hong and Stein (1999). They begin by sorting a large universe of stocks into deciles based on size as a measure for the rate of information diffusion. They find that momentum profits are surprisingly negative for the smallest stocks and then rise until the third decile where they are highest. From the third to the eighth portfolio they fall as predicted by their theory and then fall further from the ninth to the tenth decile. The authors argue that even if size might be a useful measure of the rate of information diffusion, it is likely to capture other things as well that potentially interfere. In a next step, they control for size and sort by residual analyst coverage, where the residual comes from a regression of coverage on firm size. Since the smallest firms have almost no analyst following, they drop those below the 20th size percentile of NYSE/AMEX stocks from their universe. Analyst coverage should serve as a better proxy for information diffusion, the key ingredient of the model by the same authors, and news should get out more slowly to the investing public for stocks with a low residual analyst coverage. Indeed momentum profits are found to be about sixty percent higher in the subsample with low coverage. Further analysis uncovers an interesting asymmetry: low coverage stocks react more sluggishly to bad news than to good news. The authors suggest that bad news might diffuse gradually to investors as corporate managers have an incentive to publish only good news to promote rising stock prices. While this argument might be plausible to explain short-run results, it is not entirely clear why the bulk of the momentum comes from looser stocks over the full holding period of six months. Even more surprising, they find that for the subsamples of winner stocks, their numbers go "the wrong way - the continuing performance of low-coverage winners is a bit worse than that of high-coverage winners". This result is not only significant, it is also inconsistent with the prediction from Hong and Stein (1999) and raises doubts on the overall validity of their empirical paper to make a persuasive case for their theory.

The latest study in this direction is made by Lee and Swaminathan (2000), who show that past trading volume predicts both the magnitude and persistence of future price momentum. A strategy of buying past high-volume winners and selling past high-volume losers significantly outperforms a univariate momentum strategy in the intermediate-term by almost one percent per month. Their 
results are independent of market liquidity, size, risk factors and industry adjustments and robust in various subperiods. Most of the predictive power of trading volume comes from recent changes in trading activity rather than from the trading level, which further supports the idea that past turnover can serve as a proxy for investor sentiment. In the spirit of the Hong and Stein (1999) model one would expect that scarcity of trading leads to insufficient diffusion of information. However, the empirical results of Lee and Swaminathan (2000) indicate that momentum strategies actually perform better among high volume stocks, where diffusion of information can be expected to be high. So the evidence either does not support the view that volume can serve as a proxy for information diffusion or casts further doubts on the predictions of this model. They do not relate their results to the predictions of Barberis, Shleifer, and Vishny (1998). The model of Daniel, Hirshleifer, and Subrahmanyam (1998) implies that high trading volume will support momentum, since it arises from positive feedback traders that seek to capitalize on an initial price move by buying on good news, which is confirmed by their results. Overall, the two studies come to opposing conclusions regarding the new theories. This calls for further research in order to present a persuasive case for one of the behavioral models.

\section{Dispersion in consensus forecasts and the formation of beliefs}

Momentum trading strategies have become a popular investment approach. Grinblatt, Titman, and Wermers (1995) find that the majority of U.S. mutual funds have recently employed momentum strategies and as a result realized a significantly better performance than other funds. The current challenge is therefore to refine their momentum screens with a stock selection process that relies on psychological evidence about how people process new information. The impact of divergent expectations of market participants on security prices and on the profitability of momentum strategies in specific has so far been neglected in the finance literature.

To use an analogy from the psychology literature, consensus forecasts can be understood as a letter of recommendation for a stock. In their seminal paper on the weighing of evidence and formation of beliefs in human thought, Griffin and Tversky (1992) use the example of a letter of recommendation for a prospective graduate student to illustrate how people form beliefs. They point out that one should consider two separate aspects: how positive it is and how credible or knowledgeable the writer. In this context it is possible to distinguish between the strength of a 
recommendation, which is equivalent to the upward or downward changes in earnings expectations, and of its weight or validity, which is represented by the dispersion in forecasts.

Experiments in the cognitive psychology have demonstrated that people do not combine strength and weight of evidence according to a rational Bayesian model when updating their beliefs. Judgments are overly influenced by the strength of evidence as people perceive it first and then some adjustments are made for other factors that control predictive validity. Edwards (1968) documents that people do not consider new sample data sufficiently and are in this sense too conservative. The treatment of the latest available information is based on an anchoring and adjustment process that takes the weight of evidence into account, though insufficiently. This is in line with the motivation of the model by Barberis, Shleifer, and Vishny (1998). Their theory implies that investors display conservatism and underreact to information that has a high weight when adjusting their beliefs. The following empirical study can therefor be regarded as an out-of-sample test of their theory. Firms can be classified a priori by the strength and weight of their earnings news and then sorted into respective portfolios. A revision in consensus forecasts with low dispersion, or in other words higher weight, is expected to result on average in a stronger impact on stock prices.

\section{Data and Sample Description}

The primary data come from the Institutional Brokerage Estimate System (IBES) international historical Data base. IBES continuously collects earnings estimates from all major brokerage houses and sells them to investors through an online system. Data from IBES are used since they cover the broadest number of analysts and provide the most comprehensive data base with the longest history of years available. The vast majority of academic studies on the price formation following earnings news have so far been made for the U.S. market, where the systematic collection of historical data first began. The international practice of asset management calls for studies on other international markets and a large number of European fund managers are currently interested in implementing a quantitative investment approach and seek for insights about the earnings data they employ. Sufficient historical data are now available to examine the German market.

To be included in the sample and in order to obtain consensus forecasts of expected earnings, a firm must be covered by a minimum of three analysts. For all firms at least one year of consecutive earnings forecasts is available. One should keep in mind that analysts tend to cover larger and actively traded firms. The sample consists of 156 months in the period of January 1987, the first month for 
which comprehensive earnings data are available, until January 2000. The sample period is thus more recent than the data used in previous studies. Daily security returns can be obtained for all stocks with historical analysts earnings information from Datastream International. The earnings and return data are then merged.

The median earnings per share estimate for the next fiscal year is obtained at the first trading day of each month and represents the consensus forecasts. The dispersion of opinions among the analysts is measured as the coefficient of variation in earnings expectations for each firm in the consensus. ${ }^{1}$ The extent of earnings news for each stock is computed as an earnings revision ratio, which is the monthly change in (average) consensus forecasts. Stocks are then ranked in descending order by their monthly earnings revision ratio and sorted according to their quintile rank into five equally weighted portfolios.

Table I provides an overview of the earnings consensus data for the full sample and for each of the five portfolios. The first interesting observation is the increasing number of firms in the sample over the years. While two decades ago professional earnings forecasting hardly existed, brokerage firms now employ a large number of analysts, which increases the number of firms with an analyst following. A further contribution to the rising number of firms is the so called 'Neuer Markt', a segment of the German stock exchange that was established in 1997 and has since then attracted numerous new listings from growth firms. Another interesting pattern, which is however recently somewhat offset by the rising number of firms, is the growing number of analysts that cover the average firm. This documents the increasing relevance of analysts' estimates and in fact most asset managers today employ consensus forecasts in their investment process.

A further noteworthy property of the earnings data is the overall level of firm valuations and dispersion during the sample period. The mean price-earnings ratios are similar, but skewed right and higher than the median ratio. Furthermore, the increasing number of high growth firms in the market and the optimism of investors for these firms at the end of the sample period is reflected by high valuations at this time. In line with this pattern is the increasing overall dispersion, since uncertainty about future earnings tends to be higher in times of technological advancement.

The last columns of Table I show the average earnings revision ratios for each of the five portfolios followed by the average dispersion in earnings forecasts for each portfolio. The first portfolio contains stocks with the most upward revision in earnings, with an average of plus 18.6 percent over all years and the fifth portfolio contains stocks with strong downward revisions, with a 
similar average of minus 19.4 percent in the sample period. The middle portfolio predominantly contains no earnings revisions, since firms report little if any value relevant changes in many months and analysts tend to cover a broad number of stocks and tent to revise their earnings estimates only when firm-specific news comes out. Consistent with the amount of news one can potentially disagree on, the dispersion in earnings forecasts is highest in the first and last portfolio, which also have the most substantial earnings revisions.

\section{Basic Earnings Revision Strategies}

This section starts with the analysis of basic earnings momentum strategies and sets the foundation for the refined strategy in the following section. Stocks are ranked in descending order on the basis of analysts' monthly earnings revisions and sorted into five equally weighted portfolios. The number of stocks in each portfolio is increasing with the number of firms in the full sample throughout the years and there are on average about 20 to 60 firms in each portfolio. Table II examines the raw returns earned by these portfolios. Returns are calculated following the event date of earnings revisions, which is chosen as the first trading date in each month. The first set of columns shows average returns over various monthly holding periods up to one year and the second set of columns shows the respective cumulative returns over the same holding periods. For a six month holding period, stocks with bullish earnings revisions have earned 5.02 percent and with bearish earnings revisions negative 1.62 percent. In order to determine whether profitable investment strategies exist with respect to analysts' earnings revisions, market-adjusted returns are calculated next for each of these portfolios. The market return is obtained by calculating a market index comprised of all traded firms with a minimum coverage of three IBES analysts, so there is no size-induced bias in the following results.

Table III presents the abnormal returns for the five portfolios and confirms the presence of significant momentum: Portfolio P1 achieves consistently higher returns than Portfolio P5 and an arbitrage portfolio which buys the first and sells short the last portfolio, P1-P5, generates significant positive returns over all holding periods. Consistent with prior research on price-momentum strategies by Jegadeesh and Titman (1993), the average monthly profits to a momentum strategy are highest for a holding period of up to six months. The following test will therefore utilize this optimal holding period of six months. The overall magnitude of the momentum effect is also comparable to previous studies with an average of around one percent abnormal returns per month. The profits are 
significantly positive: over the six month holding periods a cumulative abnormal return of 6.64 percent $(t$-statistic $=12.23)$ is found.

\section{Dispersion in Consensus Forecasts and Momentum Profits}

Having established the fact that basic momentum strategies are profitable in this sample, the effect of dispersion in consensus forecasts can now be examined. The rational for dispersion as a relevant variable is that it measures the disagreement among analysts and reflects the level of consensus among market participants about future earnings, which are the central ingredient to value a firm. Dispersion can also serve as a proxy for the prior uncertainty that a given firm will realize expected earnings. When uncertainty about a firm's prospects' is low, there is little dispersion.

In order to capture the effect of dispersion, the stocks of each of the earnings momentum portfolios are sorted independently by their dispersion into three equally-weighted sub-portfolios, which results in a total of 15 sub-samples. A finer breakdown to filter the effect of dispersion even further is not feasible for this universe of stocks as a researcher should be cautious not to reach a point where the individual portfolios contain only a small number of individual stocks, which can result in undiversified portfolios that create larger standard errors in the required test statistic. In practical applications, a larger number of sub-portfolios can be chosen to generate potentially stronger results. In order to determine the optimal number of sub-portfolios, portfolio mangers face a trade off between the number of stocks they want to invest in, which decreases the number of potential subportfolios and the total number of stocks in their respective universe, which can increase the number of potential sub-portfolios. For instance in a Pan-European investment approach, the effect of dispersion might be filtered even further, whereas a portfolio manger who is focused on one particular industry can only screen the respective stocks with a smaller number of sub-portfolios. The subportfolios are labeled CV1 for the stocks with high, CV2 for stocks with a medium and CV3 for stocks with a low dispersion. Finally the returns for a portfolio that is long in the stocks of CV3 and short those in CV1, a low-minus-high dispersion portfolio, CV3-CV1, are computed. The raw returns for these portfolios are depicted in Table IV and market-adjusted returns in Table V.

A clear pattern emerges by comparing the returns of the high and low dispersion portfolios: there is stronger momentum in the stocks with low dispersion. First, the stocks in sub-portfolio P1/CV3 with upward earnings revisions and low dispersion earn higher returns than those with low dispersion in P1/CV1 and second, the negative stock returns in the sub-portfolio P5/CV3 are more 
pronounced for low dispersion stocks than for high dispersion stocks in P5/CV1. An important side result is that basic momentum is present in each of the three sub-portfolios, which further documents its robustness. The fourth column shows the differential effect of dispersion for each of the earnings momentum portfolios and confirms that the effect is present in each of the earnings revisions portfolios, however not of a statistically significant magnitude in portfolio P5 with downward revisions. This indicates that a consensus among analysts is important in disseminating corporate information to the market, but more so for good news than for bad news.

The importance of a consensus in the latest expected earnings estimates to move stock prices upwards can be explained by the well known fact among market participants that analysts tend to be overly optimistic. The forecasts for this study are obtained from IBES, who collect and disseminate earnings estimates from sell-side analysts of brokerage houses, who in turn receive most of their information from corporate executives that have an incentive to give them optimistic information about the firms they manage. In addition, many analysts are an implicit part of the investment banking relationships with the firms they cover and are therefore inclined to communicate rather positive earnings forecasts to the market in order to please their clients. Portfolio managers understand the role of executives, analysts and investors in this earnings game. They will therefore be alerted and already ready to sell when few analysts make strong downward revisions in their earnings forecasts. Upward revisions however will only be convincing to investors when a broad number of analysts agree to the improved prospects of a firm or in other words when the respective dispersion in earnings forecasts is low. As a result, when stock prices underreact they do so more to good news than to bad news.

The key finding of this study is that the effect of dispersion on the overall profitability of the earnings revision strategy, or in other words the return of the P1-P5/CV3-CV1 portfolio, is not only highly statistically significant with a $t$-statistic of 3.31 , but also of an amazing economic magnitude with an incremental return of 0.95 percent per month. Furthermore, the difference in returns is not only of substantial absolute, but also of an impressive relative order. For high dispersion stocks the arbitrage portfolio P1-P5 yields 0.80 percent per month and for low dispersion stocks 1.74 percent. Thus the momentum profits are more than twice as high in the CV3 than in CV1 portfolio.

The second essential result from Table $\mathrm{V}$ is that the effect of dispersion is statistically significant and of substantial economic magnitude in the portfolios with upward earnings revisions, with a differential effect of dispersion on the returns in $\mathrm{P} 1$ of 0.68 percent per month ( $t$-statistic 3.90$)$. Portfolio managers can therefore also implement an alternative trading strategy based on the 
dispersion effect alone and create a new style or investment category, which has no exposure to the momentum factor. A recent article on mutual fund performance by Wermers (2000) is noteworthy in this respect. He decomposes fund returns by their stock-picking talent, style and expenses. His result, which is at odds with most prior studies on performance measurement, is that high-turnover funds, although incurring substantially higher transactions costs and charging higher expenses, also hold stocks with much higher average returns than low-turnover funds and beat their characteristic benchmark index, supporting the value of active fund management. A portion of this higher return level is found to be due to the better stock-picking skills of these managers, even after controlling for the type of stocks they hold (i.e. large, growth, high momentum stocks). The differential dispersion strategy offers an opportunity in this direction: an investor who believes that earnings momentum is associated with some unknown source of systematic risk, will buy the stocks in P1/CV3 and go short the stocks in P1/CV1. In the sample period, a significant return of 0.68 percent per month was achieved with a strategy that is not only market-neutral, but also momentum-neutral. Furthermore, any advocate of conventional risk-return stories will have to acknowledge that low dispersion stocks are at best less risky by traditional measures than high dispersion stocks and that this strategy, which has no loading on economically meaningful risk factors whatsoever, clearly supports a behavioral story of conservatism. In real-world markets, less than fully rational investors incorporate information into prices slowly and focus too little on the weight of new evidence.

The incremental effect of dispersion on returns is further examined in Table VI for various holding periods. The payoffs for the portfolios which are long the low and short the high dispersion stocks are shown for stocks with upward earnings revisions, P1, downward revisions, P5, and the arbitrage portfolio, P1-P5, following the event date of the analyst revisions. The results from the last row reveal that the bulk of the dispersion effect kicks in over the first six months and only significantly adds to the profits of a momentum strategy over this holding period. Consistent with this result, the average monthly profits of the basic momentum strategy are highest over six months as well, making it the optimal holding period to trade on both revisions in analysts' consensus forecasts and their dispersion.

Finally, the payoffs of the dispersion strategy over the time of the sample period are analyzed in Table VII for three subperiods. The same analysis as in Table V is done for the P1, P5 and the P1P5 momentum portfolio for the respective sub-portfolios for high, mid and low dispersion stocks. Two results are noteworthy. First, there is momentum in each sub-portfolio in all sub-periods, 
confirming its robustness, and more importantly the incremental effect of dispersion on the profits of the momentum portfolio is also present in all subperiods. A closer examination of the magnitude of these incremental returns however uncovers a second somewhat surprising result. In the 1987 to 1991 period the incremental return of a momentum strategy in low dispersion stocks is 1.70 percent per month, with a $t$-statistic of 3.31. This is followed by a lower return of 0.69 percent per month, with a $t$-statistic of 1.97 , from 1991 to 1995 and finally goes down to 0.51 percent per month, with an insignificant $t$-statistic of 0.90 . While the dispersion effect is positive in all sub-periods, it declined over time.

Dedicated followers of market efficiency will offer a straightforward interpretation: smart market participants have recognized the effect over the last years. As a result of their learning process, they will have transferred funds into low dispersion stocks which finally brought the abnormal returns down to a non-significant level. One should be cautious to jump to this conclusion. According to the traditional paradigm, prices must equal fundamental values, either because all investors are rational or because arbitrage will eliminate mispricings. The behavioral finance approach however challenges this view and stresses that in actual financial markets, less than fully rational investors trade against arbitrageurs whose resources are limited by risk aversion and short horizons. As the overall riskbearing capacity of the few specialized funds that arbitrageurs manage in any given market is bounded, their aggregate ability to bring returns of low dispersion stocks in line with fundamental values will necessarily be constraint as well. As a consequence, arbitrage remains limited and substantial mispricings can continue to exist.

Portfolio managers should keep in mind that other anomalies which can be explained by biased investor expectations have performed similarly in the past. Value stocks, for example, have underperformed growth stocks at the end of the millennium, nevertheless they have generated superior returns more recently and on an historical average about two thirds of the time. ${ }^{2}$ Furthermore is it far from obvious that investors learn from the short history of earnings expectations data that only recently accessible through electronic databases and eventually uncover and utilize the patterns in the data. From a psychological perspective, there is extensive evidence that it is difficult for people to shake off prevailing conventions such as conservatism.

The ultimate question is therefore whether the dispersion effect will continue to exist following this publication. It lies in the nature of profitable investment opportunities such as the one presented here that they are not only hard to identify, but it is generally difficult to construct matching 
portfolios of stocks with similar characteristics, i.e. of the low dispersion stocks investors want to hold and the positions they want to be short at the same time. The effectiveness of arbitrage however relies crucially on the availability of close substitutes for securities whose prices are potentially affected by noise trading. To lay off their risks, arbitrageurs who identify undervalued stocks must be able to sell short essentially similar securities. The limited number of stocks in the German market for which consensus forecasts are available make it even more challenging to construct such a riskless arbitrage portfolio. While low dispersion stocks underreact to earnings revisions on average, a trading strategy that seeks to exploit this effect is can generate abnormal returns in the long run, but its instant profitability can never be certain. This serves as a basis for the continued existence of the dispersion effect. The broader behavioral lesson from this study is then that there is empirical support for the notion that investors adapt insufficiently to the arrival of new information and underweight useful statistical evidence just like other individuals. As the dispersion effect reflects the enduring psychological phenomenon of conservatism, it is likely to persist.

\section{Conclusions}

The dispersion in analysts' consensus forecasts contains valuable information to predict the stock price formation following monthly earnings revisions. Consistent with prior research, this paper documents that prices drift in the direction of earnings revisions and that it takes up to six months until the bulk of the new information is incorporated into prices. It is the first empirical study that examines earnings forecasts for the German market and shows that a portfolio which holds stocks with upward revisions and sells short those with downward revisions yields abnormal returns, thus confirming that the success of studies in other markets has not been the result of data mining. More importantly, it is found that the profitability of this trading strategy is significantly higher for stocks with a low dispersion in consensus forecasts.

The dispersion in consensus forecasts has so far been a neglected factor in securities valuation and allows to rank stocks by both the strength and weight of their respective news. The strength of new information is represented by the extend of earnings revisions and its statistical weight by the dispersion. A low dispersion corresponds to a consensus among the analysts and more credible information. In the period of 1987 to 2000, a portfolio of high dispersion stock that is long upward revisions stocks and short downward revisions stocks for a period of six months, yields a return of 
0.80 percent per month. The same strategy applied to a portfolio of low dispersion stocks yields 1.74 percent per month, an additional 95 basis points per month.

This result can not be explained by standard asset pricing models and constitutes a semistrong inefficient market. A diversified portfolio of stocks with favorable earnings news is by no means more risky than a portfolio of stocks with unfavorable news and low dispersion stocks, in which the highest returns are earned, are at best less risky. Three alternative behavioral theories have recently been proposed that try to explain the source of the profits from short-horizon investment strategies that exploit the underreaction of prices to fundamental news. These theories differ in their assumptions regarding investor behavior. The models of Daniel, Hirshleifer and Subrahmanyam (1998) and Hong and Stein (1999) imply that misvaluations should be strongest in firms with information asymmetries. The dispersion in consensus forecasts measures the disagreement of analysts and investors on firms future prospects and can therefore serve as a proxy for information asymmetries among market participants. According to the two models, momentum should be strongest in firms that have a high dispersion. This study come to opposing results and therefore casts doubts on the validity of these models.

The model of Barberis, Shleifer and Vishny (1998) is motivated by the psychological phenomenon of conservatism, where individuals update their beliefs slowly and in revising their forecasts focus on the strength of new evidence but insufficiently on its weight. The empirical analysis in this study is performed in this spirit and can be regarded as the first out-of-sample test so far of their model. The testable hypothesis regarding dispersion is diametrically opposed to the other theories and suggests that there should be stronger momentum in low dispersion stocks, which is clearly confirmed by the empirical evidence. The field of behavioral finance is currently at an evolutionary stage and seeks to understand the sources of predictable components in stock returns. The empirical results presented in this paper favor a behavioral theory that is based on conservatism and demonstrate how superior returns can be achieved by exploiting the underreaction phenomenon. 


\section{ENDNOTES}

${ }^{1}$ The respective datatypes in the IBES database are FIMN for the median EPS forecasts and FICV for the coefficient of variation in analysts forecasts.

${ }^{2}$ La Porta (1996) shows that value stocks earn high returns not because they have higher fundamental risk, but because analysts are excessively bullish for the stocks they are most optimistic about and excessively bearish for the stocks they are most pessimistic about. The market eventually learns when earnings are announced that their valuations have been too extreme. This result is likewise at odds with the efficient market hypothesis as the empirical findings of this study and can be rationalized with the psychological evidence of Kahneman and Tversky (1973) who show that individual's beliefs are not Bayesian. It takes time for investors to become aware of new trends, but once they do, they hold onto perceived trends for too long. 


\section{REFERENCES}

Ball, Ray, and Philip Brown, 1968, An empirical evaluation of accounting income numbers, Journal of Accounting Research 6, 159-178.

Barber, Brad, Reuven Lehavy, Meureen McNichols, and Brett Truemann, 2001, Can Investors Profit from the Prophets? Security Analyst Recommendations and Stock Returns, Journal of Finance 56, 531-563.

Barberis, Nicholas, Andrei Shleifer, and Robert Vishny, 1998, A model of investor sentiment, Journal of Financial Economics 49, 307-343.

Bernard, Victor L., and Jacob K. Thomas, 1989, Post-earnings-announcement drift: Delayed price response or risk premium? Journal of Accounting Research 27, 1-36.

Chan, Kalok, Allaudeen Hameed, and Wilson Tong, 2000, Profitability of Momentum Strategies in the International Equity Markets, Journal of Financial and Quantitative Analysis 35, 153-172.

Chan, Louis K. C., Narasimhan Jegadeesh, and Josef Lakonishok, 1996, Momentum strategies, Journal of Finance 51, 1681-1713.

Cooper, Rick A., Theodore E. Day and Craig M. Lewis, 2001, Following the Leader: A Study of Individual Analysts' Earnings Forecasts, forthcoming, Journal of Financial Economics.

Cowles, Alfred, 1933, Can stock market forecasters forecast? Econometrica, 1.

Daniel, Kent D., David Hirshleifer, and Avanidhar Subrahmanyam, 1998, Investor psychology and security market under- and overreactions, Journal of Finance 53, 1839-1885.

Dische, Andreas, and Heinz Zimmermann, 1999, Consensus Forecasts of Corporate Earnings Changes and the Performance of Swiss Stocks, Journal of Investing 8, 19-26.

Edwards, Ward, 1968, Conservatism in human information processing, in: Kleinmuntz, Benjamin, ed.: Formal representation of human judgment. Wiley, New York.

Einhorn, Hillel J., 1980, Overconfidence in judgment, New Directions for Methodology of Social and Behavioral Science 4, 1-16.

Fama, Eugene F., 1998, Market efficiency, long-term returns, and behavioral finance, Journal of Financial Economics 49, 283-306. 
Fama, Eugene F., and Kenneth R. French, 1996, Multifactor explanations of asset pricing anomalies, Journal of Finance 51, 55-84.

Griffin, D., and A. Tversky, 1992, The weighting of evidence and the determinants of confidence, Cognitive Psychology 24, 411-435.

Grinblatt, Mark, Sheridan Titman, and Russ Wermers, 1995, Momentum investment strategies, portfolio performance, and herding: A study of mutual fund behavior, American Economic Review 85, 1088-1105.

Grundy, Bruce D., and J. Spencer Martin, 2001, Understanding the nature of the risks and the sources of the rewards to momentum investing, Review of Financial Studies 14, $29-78$.

Haugen, Robert A., and Nardin L. Baker, 1996, Commonality in the determinants of expected stock returns, Journal of Financial Economics 41, 401-439.

Hong, Harrison, and Jeremy C. Stein, 1999, A unified theory of underreaction, momentum trading, and overreaction in asset markets, Journal of Finance 54, 2143-2184.

Hong, Harrison, Terence Lim, and Jeremy C. Stein, 2000, Bad news travels slowly: Size, analyst coverage, and the profitability of momentum strategies, Journal of Finance 55, 265-295.

Jegadeesh, Narasimhan, and Sheridan Titman, 1993, Returns to buying winners and selling losers: Implications for stock market efficiency, Journal of Finance 48, 65-91.

Jegadeesh, Narasimhan, and Sheridan Titman, 2001, Profitability of momentum strategies: An evaluation of alternative explanations, Journal of Finance, forthcoming.

Kahneman, Daniel, and Amos Tversky, 1973, On the Psychology of Prediction, Psychological Review, 80, 237-291.

La Porta, Rafael, 1996, Expectations and the cross-section of stock returns, Journal of Finance 51, 1715-1742.

Lee, Charles M. C., and Bhaskaran Swaminathan, 2000, Price Momentum and Trading Volume, Journal of Finance 55, 2017-2069.

Rouwenhorst, K. Geert, 1998, International momentum strategies, Journal of Finance 53, 267-284. 
Rouwenhorst, K. Geert, 1999, Local return factors and turnover in emerging stock markets, Journal of Finance 54, 1439-1464.

Wermers, Russ, 2000, Mutual Fund Performance: An Empirical Decomposition into Stock-Picking Talent, Style, Transaction Costs, and Expenses, Journal of Finance 55, 1655-1695.

Womack, Kent L., 1996, Do brokerage analysts' recommendations have investment value? Journal of Finance 51, 137-168. 
Table I

\section{Descriptive Statistics of Analysts Forecasts}

Descriptive statistics of analyst forecasts for all German firms with a minimum coverage of three analysts in the period of 1987 to 2000 . Earnings forecasts for the next fiscal year are obtained from the IBES historical database on the first trading day each month. The median number of analysts per covered firm is shown, as is the mean and median $\mathrm{P} / \mathrm{E}$, followed by the mean earnings per share and dispersion in consensus forecasts. Dispersion is the coefficient of variation of all earnings estimates, measured as the standard deviation of all estimates that make up the consensus as a percentage of the absolute value of the mean value of all estimates for a company. Revision ratios are computed as the average monthly change in expected earnings per share as a percentage of the absolute value of the last consensus forecasts. Stocks are ranked in descending order on the basis of their earnings revision ratios into five equally weighted portfolios and then the average revision ratio and dispersion of each portfolio is reported for each year.

\begin{tabular}{|c|c|c|c|c|c|c|c|c|c|c|c|c|c|c|c|c|}
\hline \multirow{2}{*}{ Year } & \multirow{2}{*}{$\begin{array}{l}\text { No. of } \\
\text { Firms }\end{array}$} & \multirow{2}{*}{$\begin{array}{l}\text { Analysts } \\
\text { per Firm }\end{array}$} & \multicolumn{2}{|c|}{$\mathrm{P} / \mathrm{E}$} & \multirow{2}{*}{ EPS } & \multirow{2}{*}{ Dispersion } & \multicolumn{5}{|c|}{ EPS Revision by Portfolios } & \multicolumn{5}{|c|}{ EPS Dispersion by Portfolios } \\
\hline & & & Median & Mean & & & I & II & III & IV & $\mathrm{V}$ & $\mathrm{I}$ & II & III & IV & $\mathrm{V}$ \\
\hline 1987 & 84 & 7 & 18.3 & 23.0 & 3.5 & 15.4 & 23.4 & 2.4 & -2.3 & -5.9 & -24.2 & 20.7 & 8.7 & 11.3 & 18.7 & 17.4 \\
\hline 1988 & 95 & 7 & 13.8 & 16.1 & 3.2 & 12.0 & 9.5 & 0.3 & 0.0 & -0.3 & -5.9 & 14.7 & 7.4 & 12.6 & 11.2 & 14.2 \\
\hline 1989 & 104 & 8 & 18.7 & 22.4 & 3.6 & 12.7 & 8.5 & 0.6 & 0.0 & 0.0 & -4.0 & 19.8 & 7.8 & 8.4 & 10.6 & 17.0 \\
\hline 1990 & 117 & 10 & 23.2 & 26.6 & 4.0 & 13.9 & 10.9 & 0.3 & 0.0 & -1.5 & -9.8 & 18.6 & 7.7 & 12.2 & 11.2 & 19.7 \\
\hline 1991 & 121 & 11 & 19.4 & 25.1 & 3.9 & 17.3 & 10.4 & 0.1 & 0.0 & -0.6 & -9.2 & 15.3 & 7.6 & 10.6 & 31.1 & 21.9 \\
\hline 1992 & 142 & 13 & 17.0 & 20.8 & 3.8 & 22.9 & 10.9 & 0.2 & 0.0 & -0.6 & -11.5 & 25.1 & 8.8 & 12.7 & 44.5 & 23.4 \\
\hline 1993 & 161 & 14 & 17.6 & 30.7 & 2.1 & 20.2 & 25.8 & 0.5 & 0.0 & -1.9 & -33.8 & 22.3 & 2.8 & 13.8 & 17.1 & 44.9 \\
\hline 1994 & 175 & 14 & 20.7 & 24.2 & 2.9 & 30.6 & 32.8 & 1.7 & 0.1 & -0.2 & -15.5 & 32.9 & 11.8 & 20.1 & 29.9 & 58.2 \\
\hline 1995 & 184 & 17 & 17.4 & 18.7 & 3.3 & 24.9 & 38.3 & 0.5 & 0.0 & -0.4 & -20.4 & 31.4 & 12.4 & 21.1 & 14.8 & 44.8 \\
\hline 1996 & 203 & 15 & 17.0 & 18.3 & 2.8 & 23.3 & 14.7 & 0.3 & 0.0 & -0.6 & -36.5 & 30.2 & 16.1 & 17.5 & 28.2 & 24.7 \\
\hline 1997 & 207 & 15 & 19.5 & 24.0 & 2.4 & 40.3 & 17.6 & 0.5 & 0.0 & -2.1 & -35.6 & 29.0 & 17.6 & 20.1 & 35.6 & 99.2 \\
\hline 1998 & 229 & 13 & 18.5 & 25.5 & 2.8 & 26.5 & 19.9 & 1.0 & 0.0 & -0.9 & -18.3 & 26.8 & 16.8 & 19.2 & 27.2 & 42.5 \\
\hline 1999 & 243 & 12 & 19.1 & 29.7 & 2.9 & 30.3 & 17.0 & 0.7 & 0.0 & -0.6 & -17.2 & 33.8 & 15.7 & 29.8 & 23.2 & 48.8 \\
\hline 2000 & 323 & 10 & 25.5 & 34.7 & 2.2 & 31.5 & 20.7 & 0.6 & 0.0 & -2.6 & -29.6 & 26.8 & 18.5 & 30.2 & 35.2 & 46.7 \\
\hline $\begin{array}{l}\text { Average } \\
\text { all years }\end{array}$ & 171 & 12 & 19.0 & 24.3 & 3.1 & 23.0 & 18.6 & 0.7 & -0.2 & -1.3 & -19.4 & 24.8 & 11.4 & 17.1 & 24.2 & 37.4 \\
\hline
\end{tabular}




\section{Table II}

\section{Earnings Momentum Strategies, 1987 to 2000}

\section{Actual Monthly Returns of Portfolios Formed on the Basis of Earnings Revisions}

This table reports actual percentage monthly returns following analysts' earnings revisions. The earnings momentum is based on the most recent analysts consensus revisions each month. The sample includes all firms listed on the German market with a minimum coverage of three IBES analysts in the time period of 1/1987 - 12/1999, which contains 156 monthly observations. Stocks are ranked in descending order into five portfolios, where P1 represents the portfolio with upward earnings revisions and P5 represents the portfolio with downward revisions. The stocks are equally weighted and there are on average about 20 to 60 firms in each portfolio. The table reports the average monthly raw returns of the five portfolios and their average cumulative returns in event time for various monthly holding periods up to one year. $t$-statistics are reported in parenthesis.

\begin{tabular}{|c|c|c|c|c|c|c|c|c|c|c|}
\hline \multirow[b]{2}{*}{ Earnings-Revision Portfolio } & \multicolumn{5}{|c|}{ Average Monthly Returns } & \multicolumn{5}{|c|}{ Cumulative Returns } \\
\hline & {$[0,1]$} & {$[1,3]$} & {$[3,6]$} & {$[6,9]$} & {$[9,12]$} & {$[0,1]$} & {$[0,3]$} & {$[0,6]$} & {$[0,9]$} & {$[0,12]$} \\
\hline P1 (most favorable) & $\begin{array}{c}0.6023 \\
(2.01)\end{array}$ & $\begin{array}{c}0.7703 \\
(3.24)\end{array}$ & $\begin{array}{c}0.9592 \\
(4.17)\end{array}$ & $\begin{array}{c}0.6187 \\
(3.04)\end{array}$ & $\begin{array}{c}0.5856 \\
(3.14)\end{array}$ & $\begin{array}{c}0.6023 \\
(2.01)\end{array}$ & $\begin{array}{c}2.1430 \\
(3.55)\end{array}$ & $\begin{array}{c}5.0205 \\
(5.41)\end{array}$ & $\begin{array}{c}6.8767 \\
(6.37)\end{array}$ & $\begin{array}{c}8.6336 \\
(7.21)\end{array}$ \\
\hline $\mathrm{P} 2$ & $\begin{array}{c}0.4402 \\
(1.48)\end{array}$ & $\begin{array}{c}0.4813 \\
(1.91)\end{array}$ & $\begin{array}{c}0.3989 \\
(2.14)\end{array}$ & $\begin{array}{c}0.3493 \\
(2.03)\end{array}$ & $\begin{array}{c}0.2314 \\
(1.23)\end{array}$ & $\begin{array}{c}0.4402 \\
(1.48)\end{array}$ & $\begin{array}{c}1.4028 \\
(2.19)\end{array}$ & $\begin{array}{c}2.5996 \\
(2.86)\end{array}$ & $\begin{array}{c}3.6476 \\
(3.58)\end{array}$ & $\begin{array}{r}4.3417 \\
(3.78)\end{array}$ \\
\hline P3 & $\begin{array}{c}0.4465 \\
(1.51)\end{array}$ & $\begin{array}{c}0.3139 \\
(1.16)\end{array}$ & $\begin{array}{c}0.2769 \\
(1.35)\end{array}$ & $\begin{array}{c}0.2423 \\
(1.38)\end{array}$ & $\begin{array}{c}0.2452 \\
(1.22)\end{array}$ & $\begin{array}{c}0.4465 \\
(1.51)\end{array}$ & $\begin{array}{l}1.0743 \\
(1.62)\end{array}$ & $\begin{array}{l}1.9049 \\
(2.04)\end{array}$ & $\begin{array}{c}2.6318 \\
(2.56)\end{array}$ & $\begin{array}{c}3.3674 \\
(2.79)\end{array}$ \\
\hline $\mathrm{P} 4$ & $\begin{array}{c}0.0832 \\
(0.28)\end{array}$ & $\begin{array}{c}0.2201 \\
(0.79)\end{array}$ & $\begin{array}{c}0.2354 \\
(1.25)\end{array}$ & $\begin{array}{c}0.3641 \\
(1.82)\end{array}$ & $\begin{array}{c}0.2384 \\
(1.36)\end{array}$ & $\begin{array}{c}0.0832 \\
(0.28)\end{array}$ & $\begin{array}{c}0.5234 \\
(0.79)\end{array}$ & $\begin{array}{c}1.2294 \\
(1.39)\end{array}$ & $\begin{array}{c}2.3216 \\
(2.32)\end{array}$ & $\begin{array}{c}3.0370 \\
(2.73)\end{array}$ \\
\hline P5 (least favorable) & $\begin{array}{c}-0.1017 \\
(-0.33)\end{array}$ & $\begin{array}{c}-0.3433 \\
(-1.56)\end{array}$ & $\begin{array}{c}-0.2773 \\
(-1.48)\end{array}$ & $\begin{array}{c}-0.0631 \\
(-0.37)\end{array}$ & $\begin{array}{c}-0.0492 \\
(-0.34)\end{array}$ & $\begin{array}{c}-0.1017 \\
(-0.33)\end{array}$ & $\begin{array}{c}-0.7883 \\
(-1.41)\end{array}$ & $\begin{array}{c}-1.6202 \\
(-1.97)\end{array}$ & $\begin{array}{c}-1.8095 \\
(-1.85)\end{array}$ & $\begin{array}{c}-1.9572 \\
(-1.77)\end{array}$ \\
\hline P1 - P5 (Arbitrage) & $\begin{array}{c}0.7040 \\
(3.54)\end{array}$ & $\begin{array}{c}1.1136 \\
(8.11)\end{array}$ & $\begin{array}{l}1.2365 \\
(8.95)\end{array}$ & $\begin{array}{c}0.6819 \\
(5.76)\end{array}$ & $\begin{array}{c}0.6349 \\
(5.39)\end{array}$ & $\begin{array}{c}0.7040 \\
(3.54)\end{array}$ & $\begin{array}{c}2.9313 \\
(8.79)\end{array}$ & $\begin{array}{l}6.6407 \\
(12.23)\end{array}$ & $\begin{array}{l}8.6862 \\
(12.22)\end{array}$ & $\begin{array}{c}10.5908 \\
(13.17)\end{array}$ \\
\hline
\end{tabular}




\section{Table III}

Market-Adjusted Abnormal Returns of Portfolios Formed on the Basis of Earnings Revisions, 1987-2000

This table reports percentage abnormal monthly returns in event time earned by portfolios formed on the basis of monthly analysts' consensus earnings revisions. Market-adjusted abnormal returns are the mean raw returns less the return of an equally-weighted index of all firms with a minimum coverage of three IBES analysts. The sample includes all firms with a minimum coverage of three analysts in the time period of 1/1987 - 12/1999, which contains 156 monthly observations. Stocks are ranked in descending order into five portfolios, where P1 represents the portfolio with upward earnings revisions and P5 represents the portfolio with downward revisions. The table reports the average monthly returns of the five portfolios and their average cumulative returns, CARs, in event time for various monthly holding periods up to one year. $t$-statistics are reported in parenthesis.

\begin{tabular}{|c|c|c|c|c|c|c|c|c|c|c|}
\hline \multirow[b]{2}{*}{ Earnings-Revision Portfolio } & \multicolumn{5}{|c|}{ Average Monthly Abnormal Returns } & \multicolumn{5}{|c|}{ Cumulative Abnormal Returns } \\
\hline & {$[0,1]$} & {$[1,3]$} & {$[3,6]$} & {$[6,9]$} & {$[9,12]$} & {$[0,1]$} & {$[0,3]$} & {$[0,6]$} & {$[0,9]$} & {$[0,12]$} \\
\hline P1 (most favorable) & $\begin{array}{c}0.3082 \\
(2.96)\end{array}$ & $\begin{array}{c}0.4819 \\
(5.80)\end{array}$ & $\begin{array}{c}0.6406 \\
(7.09)\end{array}$ & $\begin{array}{c}0.3165 \\
(4.78)\end{array}$ & $\begin{array}{c}0.3354 \\
(5.81)\end{array}$ & $\begin{array}{c}0.3082 \\
(2.96)\end{array}$ & $\begin{array}{c}1.2719 \\
(6.89)\end{array}$ & $\begin{array}{l}3.1936 \\
(10.55)\end{array}$ & $\begin{array}{l}4.1430 \\
(11.42)\end{array}$ & $\begin{array}{l}5.1491 \\
(12.86)\end{array}$ \\
\hline $\mathrm{P} 2$ & $\begin{array}{c}0.1461 \\
(1.23)\end{array}$ & $\begin{array}{c}0.1928 \\
(2.65)\end{array}$ & $\begin{array}{c}0.0803 \\
(1.46)\end{array}$ & $\begin{array}{c}0.0471 \\
(0.80)\end{array}$ & $\begin{array}{c}-0.0189 \\
(-0.29)\end{array}$ & $\begin{array}{c}0.1461 \\
(1.23)\end{array}$ & $\begin{array}{c}0.5318 \\
(2.60)\end{array}$ & $\begin{array}{c}0.7728 \\
(3.02)\end{array}$ & $\begin{array}{c}0.9139 \\
(2.78)\end{array}$ & $\begin{array}{c}0.8572 \\
(2.16)\end{array}$ \\
\hline P3 & $\begin{array}{c}0.1524 \\
(1.53)\end{array}$ & $\begin{array}{c}0.0254 \\
(0.35)\end{array}$ & $\begin{array}{c}-0.0417 \\
(-0.65)\end{array}$ & $\begin{array}{c}-0.0599 \\
(-1.22)\end{array}$ & $\begin{array}{c}-0.0051 \\
(-0.08)\end{array}$ & $\begin{array}{c}0.1524 \\
(1.53)\end{array}$ & $\begin{array}{c}0.2033 \\
(1.17)\end{array}$ & $\begin{array}{c}0.0780 \\
(0.28)\end{array}$ & $\begin{array}{c}-0.1018 \\
(-0.31)\end{array}$ & $\begin{array}{r}-0.1171 \\
(-0.30)\end{array}$ \\
\hline P4 & $\begin{array}{c}-0.2109 \\
(-1.94)\end{array}$ & $\begin{array}{c}-0.0684 \\
(-0.77)\end{array}$ & $\begin{array}{c}-0.0833 \\
(-1.37)\end{array}$ & $\begin{array}{c}0.0618 \\
(0.94)\end{array}$ & $\begin{array}{c}-0.0118 \\
(-0.17)\end{array}$ & $\begin{array}{c}-0.2109 \\
(-1.94)\end{array}$ & $\begin{array}{c}-0.3477 \\
(-1.62)\end{array}$ & $\begin{array}{c}-0.5974 \\
(-2.06)\end{array}$ & $\begin{array}{c}-0.4120 \\
(-1.17)\end{array}$ & $\begin{array}{r}-0.4475 \\
(-1.10)\end{array}$ \\
\hline P5 (least favorable) & $\begin{array}{c}-0.3958 \\
(-3.05)\end{array}$ & $\begin{array}{c}-0.6318 \\
(-6.28)\end{array}$ & $\begin{array}{c}-0.5959 \\
(-8.20)\end{array}$ & $\begin{array}{c}-0.3654 \\
(-5.20)\end{array}$ & $\begin{array}{c}-0.2995 \\
(-3.59)\end{array}$ & $\begin{array}{c}-0.3958 \\
(-3.05)\end{array}$ & $\begin{array}{c}-1.6593 \\
(-6.71)\end{array}$ & $\begin{array}{c}-3.4470 \\
(-9.51)\end{array}$ & $\begin{array}{c}-4.5432 \\
(-9.56)\end{array}$ & $\begin{array}{l}-5.4417 \\
(-10.01)\end{array}$ \\
\hline P1 - P5 (Arbitrage) & $\begin{array}{c}0.7040 \\
(3.54)\end{array}$ & $\begin{array}{l}1.1136 \\
(8.11)\end{array}$ & $\begin{array}{l}1.2365 \\
(8.95)\end{array}$ & $\begin{array}{c}0.6819 \\
(5.76)\end{array}$ & $\begin{array}{c}0.6349 \\
(5.39)\end{array}$ & $\begin{array}{c}0.7040 \\
(3.54)\end{array}$ & $\begin{array}{c}2.9313 \\
(8.79)\end{array}$ & $\begin{array}{l}6.6407 \\
(12.23)\end{array}$ & $\begin{array}{l}8.6862 \\
(12.22)\end{array}$ & $\begin{array}{c}10.5908 \\
(13.17)\end{array}$ \\
\hline
\end{tabular}




\section{Table IV}

\section{Actual Returns over Six Months of Portfolios}

Formed by Earnings Revisions and Dispersion in Analysts Forecasts, 1987 to 2000

This table reports actual percentage monthly returns earned by portfolios formed on the basis of monthly analysts' consensus earnings revisions and held for six months. The sample includes all firms with a minimum coverage of three IBES analysts in the time period of 1/1987 - 12/1999. Stocks are ranked in descending order into five portfolios, where P1 represents the portfolio with upward earnings revisions and P5 represents the portfolio with downward revisions. Within each earningsrevision portfolio, three further sub-portfolios are formed based on the dispersion in consensus forecasts. The first third of firms with the highest dispersion are in CV1, the second third of firms with medium dispersion are in CV2 and stocks with the lowest dispersion are in CV3. $t$-statistics are reported in parenthesis.

Sub-Portfolios by Dispersion in Consensus Forecasts

\begin{tabular}{|c|c|c|c|c|}
\hline Earnings-Revision Portfolio & $\begin{array}{l}\text { High } \\
\text { CV1 }\end{array}$ & $\begin{array}{l}\text { Mid } \\
\text { CV2 }\end{array}$ & $\begin{array}{l}\text { Low } \\
\text { CV3 }\end{array}$ & $\begin{array}{l}\text { Low - High } \\
\text { CV3 - CV1 }\end{array}$ \\
\hline $\mathrm{P} 1$ & $\begin{array}{c}0.6039 \\
(2.44)\end{array}$ & $\begin{array}{c}0.6155 \\
(6.05)\end{array}$ & $\begin{array}{c}1.2887 \\
(6.94)\end{array}$ & $\begin{array}{c}0.6848 \\
(3.90)\end{array}$ \\
\hline $\mathrm{P} 2$ & $\begin{array}{c}0.1634 \\
(0.67)\end{array}$ & $\begin{array}{c}0.2656 \\
(4.15)\end{array}$ & $\begin{array}{c}0.8708 \\
(4.59)\end{array}$ & $\begin{array}{c}0.7074 \\
(4.09)\end{array}$ \\
\hline $\mathrm{P} 3$ & $\begin{array}{c}-0.0259 \\
(-0.10)\end{array}$ & $\begin{array}{c}0.2622 \\
(3.90)\end{array}$ & $\begin{array}{c}0.7161 \\
(3.71)\end{array}$ & $\begin{array}{c}0.7419 \\
(4.49)\end{array}$ \\
\hline $\mathrm{P} 4$ & $\begin{array}{c}0.0035 \\
(0.02)\end{array}$ & $\begin{array}{c}0.2192 \\
(3.32)\end{array}$ & $\begin{array}{c}0.3920 \\
(2.28)\end{array}$ & $\begin{array}{c}0.3886 \\
(3.06)\end{array}$ \\
\hline P5 & $\begin{array}{c}-0.1920 \\
(-0.84)\end{array}$ & $\begin{array}{l}-0.1630 \\
(-2.14)\end{array}$ & $\begin{array}{l}-0.4551 \\
(-2.30)\end{array}$ & $\begin{array}{c}-0.2630 \\
(-1.11)\end{array}$ \\
\hline P1 - P5 & $\begin{array}{c}0.7959 \\
(3.68)\end{array}$ & $\begin{array}{c}0.7785 \\
(7.86)\end{array}$ & $\begin{array}{l}1.7437 \\
(11.71)\end{array}$ & $\begin{array}{c}0.9478 \\
(3.31)\end{array}$ \\
\hline
\end{tabular}


Table V

Market-Adjusted Abnormal Returns over Six Months of Portfolios

Formed by Earnings Revisions and Dispersion in Analysts Forecasts, 1987 to 2000

This table reports average cumulative abnormal returns, CARs, earned by portfolios formed on the basis of monthly analysts' consensus earnings revisions and held for six months. Market-adjusted abnormal returns are the mean raw returns less the return of an equally-weighted index of all firms with a minimum coverage of three IBES analysts in the time period of 1/1987 - 12/1999. Stocks are ranked in descending order into five portfolios, where P1 represents the portfolio with upward earnings revisions and P5 represents the portfolio with downward revisions. Within each earnings-revision portfolio, three further sub-portfolios are formed based on the dispersion in consensus forecasts. The first third of firms with the highest dispersion are in CV1, the second third of firms with medium dispersion are in CV2 and stocks with the lowest dispersion are in CV3. $t$-statistics are reported in parenthesis.

\begin{tabular}{|c|c|c|c|c|}
\hline \multirow[b]{2}{*}{ Earnings-Revision Portfolio } & \multicolumn{4}{|c|}{ Sub-Portfolios by Dispersion in Consensus Forecasts } \\
\hline & $\begin{array}{l}\text { High } \\
\text { CV1 }\end{array}$ & $\begin{array}{l}\text { Mid } \\
\text { CV2 }\end{array}$ & $\begin{array}{l}\text { Low } \\
\text { CV3 }\end{array}$ & $\begin{array}{l}\text { Low - High } \\
\text { CV3 - CV1 }\end{array}$ \\
\hline $\mathrm{P} 1$ & $\begin{array}{c}0.2994 \\
(2.18)\end{array}$ & $\begin{array}{c}0.3110 \\
(2.61)\end{array}$ & $\begin{array}{l}0.9842 \\
(10.36)\end{array}$ & $\begin{array}{c}0.6848 \\
(3.90)\end{array}$ \\
\hline $\mathrm{P} 2$ & $\begin{array}{c}-0.1411 \\
(-1.12)\end{array}$ & $\begin{array}{c}-0.0388 \\
(-0.41)\end{array}$ & $\begin{array}{c}0.5663 \\
(5.31)\end{array}$ & $\begin{array}{c}0.7074 \\
(4.09)\end{array}$ \\
\hline P3 & $\begin{array}{c}-0.3303 \\
(-2.40)\end{array}$ & $\begin{array}{c}-0.0423 \\
(-0.46)\end{array}$ & $\begin{array}{c}0.4116 \\
(4.35)\end{array}$ & $\begin{array}{c}0.7419 \\
(4.49)\end{array}$ \\
\hline P4 & $\begin{array}{c}-0.3010 \\
(-2.70)\end{array}$ & $\begin{array}{c}-0.0853 \\
(-0.92)\end{array}$ & $\begin{array}{c}0.0876 \\
(1.04)\end{array}$ & $\begin{array}{c}0.3886 \\
(3.06)\end{array}$ \\
\hline P5 & $\begin{array}{l}-0.4965 \\
(-2.84)\end{array}$ & $\begin{array}{c}-0.4675 \\
(-4.88)\end{array}$ & $\begin{array}{c}-0.7595 \\
(-7.04)\end{array}$ & $\begin{array}{l}-0.2630 \\
(-1.11)\end{array}$ \\
\hline P1 - P5 & $\begin{array}{c}0.7959 \\
(3.68)\end{array}$ & $\begin{array}{c}0.7785 \\
(7.86)\end{array}$ & $\begin{array}{l}1.7437 \\
(11.71)\end{array}$ & $\begin{array}{c}0.9478 \\
(3.31)\end{array}$ \\
\hline
\end{tabular}




\section{Table VI}

\section{Abnormal Returns for Various Holding Periods of the Low-Minus-High Dispersion Portfolios}

Formed on the Basis of Earnings Revisions and Dispersion in Analysts Forecasts, 1987 to 2000

This table reports average cumulative abnormal returns, CARs, earned by portfolios formed on the basis of monthly analysts' consensus earnings revisions. The sample includes all firms with a minimum coverage of three IBES analysts in the time period of 1/1987 - 12/1999. Stocks are ranked in descending order into five portfolios and the portfolios with the most and least favorable ranked stocks as well as the arbitrage portfolio are presented. The table reports the average monthly returns of these portfolios and their average monthly cumulative returns over time for various holding periods up to one year. Within each earningsrevision portfolio, three further sub-portfolios are formed based on the dispersion in consensus forecasts. The first third of firms with the highest dispersion are in $\mathrm{CV} 1$, the second third of firms with medium dispersion are in CV2 and stocks with the lowest dispersion are in CV3. $t$-statistics are reported in parenthesis.

\begin{tabular}{|c|c|c|c|c|c|c|c|c|c|c|}
\hline \multirow[b]{2}{*}{$\begin{array}{l}\text { Earnings-Revision Sub-Portfolio } \\
\text { for low minus high dispersion }\end{array}$} & \multicolumn{5}{|c|}{ Average Monthly Returns } & \multicolumn{5}{|c|}{ Cumulative Abnormal Returns } \\
\hline & {$[0,1]$} & {$[1,3]$} & {$[3,6]$} & {$[6,9]$} & {$[9,12]$} & {$[0,1]$} & {$[0,3]$} & {$[0,6]$} & {$[0,9]$} & {$[0,12]$} \\
\hline $\mathrm{P} 1$ & $\begin{array}{c}0.7981 \\
(2.13)\end{array}$ & $\begin{array}{c}0.6040 \\
(2.37)\end{array}$ & $\begin{array}{l}0.7010 \\
(3.05)\end{array}$ & $\begin{array}{l}0.7523 \\
(3.22)\end{array}$ & $\begin{array}{r}0.3932 \\
(1.85)\end{array}$ & $\begin{array}{c}0.7981 \\
(2.13)\end{array}$ & $\begin{array}{c}2.0061 \\
(3.00)\end{array}$ & $\begin{array}{l}4.1090 \\
(3.90)\end{array}$ & $\begin{array}{c}6.3658 \\
(4.45)\end{array}$ & $\begin{array}{l}7.5455 \\
(4.54)\end{array}$ \\
\hline P5 & $\begin{array}{c}-0.4820 \\
(-1.12)\end{array}$ & $\begin{array}{c}-0.4176 \\
(-1.24)\end{array}$ & $\begin{array}{c}-0.0870 \\
(-0.28)\end{array}$ & $\begin{array}{c}0.2063 \\
0.88\end{array}$ & $\begin{array}{c}0.2337 \\
1.16\end{array}$ & $\begin{array}{c}-0.4820 \\
(-1.12)\end{array}$ & $\begin{array}{c}-1.3171 \\
(-1.51)\end{array}$ & $\begin{array}{c}-1.5780 \\
(-1.11)\end{array}$ & $\begin{array}{c}-0.9591 \\
(-0.60)\end{array}$ & $\begin{array}{r}-0.2581 \\
(-0.15)\end{array}$ \\
\hline $\mathrm{P} 1$ - P5 & $\begin{array}{c}1.2801 \\
2.28\end{array}$ & $\begin{array}{l}1.0216 \\
2.24\end{array}$ & $\begin{array}{c}0.7879 \\
2.20\end{array}$ & $\begin{array}{c}0.5460 \\
1.68\end{array}$ & $\begin{array}{c}0.1596 \\
0.59\end{array}$ & $\begin{array}{c}1.2801 \\
2.28\end{array}$ & $\begin{array}{c}3.3232 \\
2.87\end{array}$ & $\begin{array}{c}5.6871 \\
3.31\end{array}$ & $\begin{array}{c}7.3250 \\
3.55\end{array}$ & $\begin{array}{c}7.8037 \\
3.45\end{array}$ \\
\hline
\end{tabular}


Table VII

Market-Adjusted Returns over Six Months of Portfolios in Subperiods

\section{Formed by Earnings Revisions and Dispersion in Analysts Forecasts, 1987 to 2000}

This table reports average cumulative abnormal returns, CARs, earned by portfolios formed on the basis of monthly analysts' consensus earnings revisions and held for six months. Market-adjusted abnormal returns are the mean raw returns less the return of an equally-weighted index of all firms with a minimum coverage of three IBES analysts in the time period of 1/1987 - 12/1999. Stocks are ranked in descending order into five portfolios and the portfolios with the most and least favorable ranked stocks as well as the arbitrage portfolio are presented. Within each earnings-revision portfolio, three further sub-portfolios are formed based on the dispersion in consensus forecasts. The first third of firms with the highest dispersion are in CV1, the second third of firms with medium dispersion are in CV2 and stocks with the lowest dispersion are in CV3. $t$-statistics are reported in parenthesis.

\begin{tabular}{|c|c|c|c|c|c|}
\hline \multirow[b]{2}{*}{ Sub-Period } & \multirow[b]{2}{*}{ Earnings-Revision Portfolio } & \multicolumn{4}{|c|}{ Sub-Portfolios by Dispersion in Consensus Forecasts } \\
\hline & & $\begin{array}{l}\text { High } \\
\text { CV1 }\end{array}$ & $\begin{array}{l}\text { Mid } \\
\text { CV2 }\end{array}$ & $\begin{array}{l}\text { Low } \\
\text { CV3 }\end{array}$ & $\begin{array}{l}\text { Low - High } \\
\text { CV3 - CV1 }\end{array}$ \\
\hline \multirow[t]{3}{*}{$1 / 1987-12 / 1990$} & $\mathrm{P} 1$ & $\begin{array}{c}0.1862 \\
(0.63)\end{array}$ & $\begin{array}{c}0.3230 \\
(1.16)\end{array}$ & $\begin{array}{l}1.5123 \\
(7.38)\end{array}$ & $\begin{array}{l}1.3261 \\
(3.35)\end{array}$ \\
\hline & P5 & $\begin{array}{c}-0.6158 \\
(-2.60)\end{array}$ & $\begin{array}{c}-0.7829 \\
(-5.22)\end{array}$ & $\begin{array}{c}-0.9874 \\
(-4.85)\end{array}$ & $\begin{array}{l}-0.3716 \\
(-1.02)\end{array}$ \\
\hline & P1 - P5 & $\begin{array}{c}0.8020 \\
(2.41)\end{array}$ & $\begin{array}{l}1.1059 \\
(4.04)\end{array}$ & $\begin{array}{c}2.4997 \\
(8.57)\end{array}$ & $\begin{array}{l}1.6977 \\
(3.31)\end{array}$ \\
\hline \multirow[t]{3}{*}{$1 / 1991-12 / 1994$} & $\mathrm{P} 1$ & $\begin{array}{c}0.1724 \\
(1.11)\end{array}$ & $\begin{array}{c}0.4253 \\
(2.87)\end{array}$ & $\begin{array}{c}0.8228 \\
(6.20)\end{array}$ & $\begin{array}{c}0.6503 \\
(3.32)\end{array}$ \\
\hline & P5 & $\begin{array}{c}-0.74 \\
(-2.95)\end{array}$ & $\begin{array}{c}-0.16 \\
(-1.13)\end{array}$ & $\begin{array}{c}-0.78 \\
(-4.85)\end{array}$ & $\begin{array}{c}-0.04 \\
(-0.12)\end{array}$ \\
\hline & P1 - P5 & $\begin{array}{c}0.9165 \\
(3.34)\end{array}$ & $\begin{array}{c}0.5862 \\
(5.59)\end{array}$ & $\begin{array}{l}1.6042 \\
(7.88)\end{array}$ & $\begin{array}{c}0.6877 \\
(1.97)\end{array}$ \\
\hline \multirow[t]{3}{*}{$1 / 1995-12 / 1999$} & $\mathrm{P} 1$ & $\begin{array}{c}0.5128 \\
(2.10)\end{array}$ & $\begin{array}{c}0.1989 \\
(1.10)\end{array}$ & $\begin{array}{c}0.6584 \\
(5.14)\end{array}$ & $\begin{array}{c}0.1456 \\
(0.53)\end{array}$ \\
\hline & P5 & $\begin{array}{c}-0.1705 \\
(-0.45)\end{array}$ & $\begin{array}{l}-0.4595 \\
(-2.47)\end{array}$ & $\begin{array}{c}-0.5375 \\
(-2.83)\end{array}$ & $\begin{array}{c}-0.3670 \\
(-0.73)\end{array}$ \\
\hline & $\mathrm{P} 1-\mathrm{P} 5$ & $\begin{array}{c}0.6833 \\
(1.47)\end{array}$ & $\begin{array}{c}0.6584 \\
(8.47)\end{array}$ & $\begin{array}{l}1.1958 \\
(4.97)\end{array}$ & $\begin{array}{c}0.5125 \\
(0.90)\end{array}$ \\
\hline
\end{tabular}

